\title{
Fossil or hydro based capacity development? - Power sector modelling in the South-East European Region
}

\author{
Zs. Pató - A. Mezősi - L. Szabó \\ Corvinus University of Budapest, \\ Regional Centre for Energy Policy Research \\ Budapest, Hungary
}

capacities compared to their total capacities and also to the European average. At the same time, natural gas has limited role in the region.

TABLE I. INSTALLED CAPACITIES (MW)

\begin{abstract}
This paper analyses the impact of current generation and interconnection capacity plans on the generation mix of the five South East European countries (Albania, Bosnia and Hercegovina, Macedonia, Montenegro, Serbia) in the context of carbon price levels and assesses the conditions for the exploitation of the existing hydro potential. Future electricity mix of the five countries are analyzed - using the European Electricity Market Model (EEMM) of REKK - for 3 scenarios up to 2030 assuming different conditions for electricity supply and demand. We have found that vulnerability due to weather dependent hydro generation is a relevant policy issue that needs to be tackled if the available hydro potential is to be exploited more in the future in the SEE region. Higher interconnection would allow for import even in dry years with a more limited number of new coal plants actually planned in the region as countries would have unconstrained access to them.
\end{abstract}

Index Terms-- Power system modeling, carbon tax, transmission lines

\section{INTRODUCTION}

The South East European (SEE) region is characterized by increasing electricity demand and relatively old fossil based power plants that need to be replaced. ${ }^{1}$ This poses an important policy question to these countries: what technologies should they promote to meet their growing electricity demand? What are the technological and policy factors - both national and European - that needs to be factored in to this decision?

This analysis focuses on five selected non-EU SEE countries: Serbia (RS) is the biggest electricity producer in the region followed by Bosnia and Herzegovina (BA) and Macedonia (MK). Some countries - e.g. Albania (AL) or Montenegro (ME) have considerable hydro generation

This paper is based on the modelling within the SLED (Support for Low-Emission Development in South Eastern Europe) project financed by the Austrian Development Agency (ADA).

${ }^{1}$ The SEE region here refers to Albania, Bosnia and Herzegovina, Bulgaria, Greece, Croatia, Hungary, Montenegro, Macedonia, Serbia and Romania.

\begin{tabular}{|l|l|c|c|c|c|c|c|c|}
\hline \multirow{2}{*}{} & \multicolumn{7}{|c|}{ Installed capacities (MW) } \\
\cline { 2 - 9 } & Coal & Gas & $\begin{array}{c}\text { Fuel } \\
\text { oil }\end{array}$ & Hydro & Wind & Biomass & PV & Total \\
\hline AL & 0 & 0 & 0 & 1801 & 0 & 5 & 2 & $\mathbf{1 8 0 7}$ \\
\hline BA & 1665 & 0 & 0 & 2251 & 0 & 0 & 0 & $\mathbf{3 9 1 6}$ \\
\hline ME & 210 & 0 & 0 & 661 & 0 & 7 & 3 & $\mathbf{8 8 1}$ \\
\hline MK & 824 & 290 & 210 & 644 & 37 & 0 & 15 & $\mathbf{2 0 2 0}$ \\
\hline RS* & 4672 & 0 & 0 & 2357 & 0 & 0 & 7 & $\mathbf{7 0 3 7}$ \\
\hline Total & $\mathbf{7 3 7 1}$ & $\mathbf{2 9 0}$ & $\mathbf{2 1 0}$ & $\mathbf{7 7 1 4}$ & $\mathbf{3 7}$ & $\mathbf{1 2}$ & $\mathbf{2 7}$ & $\mathbf{1 5 6 6 1}$ \\
\hline
\end{tabular}

Source: EEMM, RS data includes Kosovo*

The SEE region still has a large hydro potential that is underutilized today. Nevertheless, SEE countries are planning to build considerable new lignite/coal capacities: in the 20152020 period almost $8000 \mathrm{MW}$ coal/lignite based units but less than $4000 \mathrm{MW}$ hydro capacities are planned to be commissioned.

The consequence of these national capacity development plans is the possible lock-in to fossil generation for the next few decades that is rational considering the competitiveness of fossil plants operating outside any carbon regime (EU Emissions Trading System (ETS) or similar $\mathrm{CO}_{2}$ taxation) but - at the same time - causes carbon leakage and can lead to a policy trap with the prospective EU membership of the countries with such aspirations (and the consequent application of EU ETS).

This paper analyses the impact of current generation and interconnection capacity plans on the generation mix of the analyzed SEE countries in the context of carbon price levels and assesses the conditions for the exploitation of the existing hydro potential.

\section{LITERATURE REVIEW: ENERGY AND CLIMATE MODELLING IN THE SEE REGION}

In the last few years South East Europe became the focus of many research initiatives. This interest is mainly driven by the fact that most SEE countries are in the waiting room of the EU accession which triggers many policy changes in these 
countries. In the energy sector they have to, for example, make their power sector more competitive to fulfil the obligations of the third energy package and at the same time to reinforce their environmental ambitions and reach the renewable targets defined in their NREAPs (National Renewable Energy Action Plan). IENE, the Institute of Energy for South East Europe produced outlook 2015-2016 for the region focusing on both the power sector and gas market developments [1]. The Joint Research Center of the EC is currently enlarging the geographic scope of its EU-TIMES model with the countries from the region in order to include the region in its European energy and environmental system modelling [2]. Some other studies were country specific: Tot carried out a case study assessment of the Albanian energy system with the IASA energy model [3]. The National Observatory of Athens published a series of sectoral modelling in the region covering low carbon mitigation option in sectors such as the transport, waste or tertiary sector in the LOCSEE project. ${ }^{2}$ The REKK modelling in the SLED project fits into the line of this research string with its main focus being the identification of decarbonisation options in selected SEE countries [4].

\section{METHODOLOGY}

The 2030 carbon emissions trajectories of the individual countries are analyzed for 3 scenarios assuming different conditions for electricity supply and demand. These assumptions are based on official documents and strategies and are specific to each country [5][6][7][8]. The Reference (REF) scenario reflects business as usual developments in the country, meaning that the official energy policy and legislative instruments that were in place by the closing date of scenario definition (July 2015) are included. The Currently Planned Policies (CPP) scenario reflects those policies that are under consideration and that could have an impact on GHG emissions. The third scenario, Ambitious Policy (AMB), represents the most advanced climate policy stand. The regional scenarios (REF, CPP, AMB) assume the realization of the same scenario in all the analysed countries concurrently.
TABLE II. SCENARIO ASSUMPTIONS

\begin{tabular}{|l|l|c|c|}
\hline \multirow{2}{*}{ Assumptions } & \multicolumn{1}{|c|}{ REF } & \multicolumn{1}{|c|}{ SPP } & AMB \\
\cline { 2 - 4 } & \multicolumn{1}{|c|}{$\begin{array}{c}\text { in } 2023 \\
\text { EU ETS }\end{array}$} & in 2025 & in 2020 \\
\hline $\begin{array}{l}\text { Introduction of } \\
\text { EU minimum } \\
\text { excise duty }\end{array}$ & in 2020 & in 2018 \\
\hline $\begin{array}{l}\text { Enforcement } \\
\text { of } \\
\text { environmental } \\
\text { standards }\end{array}$ & $\begin{array}{l}\text { Closure } \\
\text { refurbishment of } \\
\text { affected PPs. }\end{array}$ & $\begin{array}{c}\text { Closure or } \\
\text { refurbishment } \\
\text { of affected PPs. }\end{array}$ & $\begin{array}{c}\text { refurbishment of } \\
\text { affected PPs. }\end{array}$ \\
\hline $\begin{array}{l}\text { RES-E } \\
\text { to }\end{array}$ & $\begin{array}{l}\text { According } \\
\text { NREAP } \\
\text { 2020 then BAU } \\
\text { NREAP until } \\
\text { 2020 then } \\
\text { moderate } \\
\text { growth }\end{array}$ & $\begin{array}{c}\text { According to } \\
\text { NREAP until } \\
\text { 2020 then } \\
\text { stronger growth }\end{array}$ \\
\hline $\begin{array}{l}\text { Planned } \\
\text { conventional } \\
\text { capacities }\end{array}$ & $\begin{array}{l}\text { Inclusion of PPs } \\
\text { plants } \\
\text { advanced } \\
\text { planning stage }\end{array}$ & $\begin{array}{c}\text { Inclusion of less } \\
\text { definite PP } \\
\text { development } \\
\text { plans }\end{array}$ & $\begin{array}{c}\text { Inclusion of less } \\
\text { definite PP } \\
\text { development } \\
\text { plans and co- } \\
\text { firing }\end{array}$ \\
\hline $\begin{array}{l}\text { Electricity } \\
\text { demand }\end{array}$ & $\begin{array}{l}\text { National REF } \\
\text { projection }\end{array}$ & $\begin{array}{c}\text { National REF+ } \\
\text { projection }\end{array}$ & $\begin{array}{c}\text { National EE } \\
\text { projection }\end{array}$ \\
\hline
\end{tabular}

The policy factors in the table all affect future generation mix. The introduction of the EU Emissions Trading System (ETS) as consequence of either EU membership or the transposition of EU law required for members of the Energy Community, or simply the introduction of a national policy instrument placing value on carbon emissions, alters the relative cost of generation technologies and hence the production possibilities. The same logic applies to the introduction of the minimum tax level on energy products required by EU legislation [10]. The electricity supply mix is affected by the introduction of European air pollution regulations: the Large Combustion Plants (LCP) Directive and the subsequent Industrial Emissions Directive (IED) force the most polluting coal plants out of operation or limit their operating hours [11][12]. The development of renewables and conventional (fossil) generation capacities is the outcome of national policy decisions and - in the case of renewables support levels. Growth in electricity demand triggers higher production from the available power plant portfolio or imports.

Future generation mix is forecasted by the European Electricity Market Model (EEMM) of REKK for each analysed country individually [13][14][15][16] and jointly [17].

\section{A. Technological details of the model}

EEMM covers 39 countries with detailed technological representation, where the whole ENTSO-E member countries are modelled in detail. Prices in the model are derived from the supply-demand balance, while those neighboring countries that strongly influence the EU electricity markets are represented by exogenous prices (Belarus, Morocco, Tunisia, Russia).

3 Carbon price is assumed to increase linearly from the present $6 € / \mathrm{t}$ to $22 € / \mathrm{t}$ by 2030 according to [9].
${ }^{2}$ Low Carbon South East Europe

http://www.locsee.eu/modeling_reports.php 
In the electricity production sector EEMM differentiates 12 technologies by fuel type. The transmission network is represented by an aggregated level: we assume one country being one node. In other words, we assume one interconnector per pair of countries, which arrives to modelling 99 transmission lines. EEMM models the production side at unit level, which means that at a pan-European level almost 3400 units are included in the model runs. Generation units are characterized by various technological factors (variable and OPEX cost, fuel used, efficiency, vintage of units), allowing the construction of the merit order for the 90 reference hours to represent the load curve with sufficient data for each European country.

\section{B. Equilibrium and main scenario assumptions}

The model calculates the simultaneous equilibrium allocation in all markets with the following properties:

- Objective function is to maximize total welfare, including producer and consumer surpluses and rent revenues at the cross-border capacities.

- Total domestic consumption is given by the aggregate electricity demand function in each country.

- Electricity trade continues between neighboring countries until market prices are equalized or transmission capacity is exhausted.

- Energy produced and imported is in balance with energy consumed and exported in each country.

Given our assumptions about demand and supply, market equilibrium always exists and is unique in the model. To simulate the price development of more complex electricity products, such as those for base load or a peak load delivery, we perform several model runs for the 90 representative hours for the year and take the weighted average of the resulting short-term prices. For more detailed description of EEMM see [18].

\section{RESULTS AND SENSITIVITY ANALYSIS}

Self-sufficiency in generation in 2015 turns into a $20-30 \%$ export (in total generation) in 2020 due to coal/lignite and hydro capacity expansion (the relative share depending on the scenario), after which this export share gradually decreases up to 2030. The differences between the scenarios are mainly due to the different volume of assumed fossil capacity in Serbia. Other RES technologies remain at moderate levels throughout the whole period. Natural gas-based generation units are utilised at very low level despite assumed new capacities in Albania, Serbia and Bosnia and Herzegovina.
Figure 1 Electricity generation mix in the focus countries (2030)

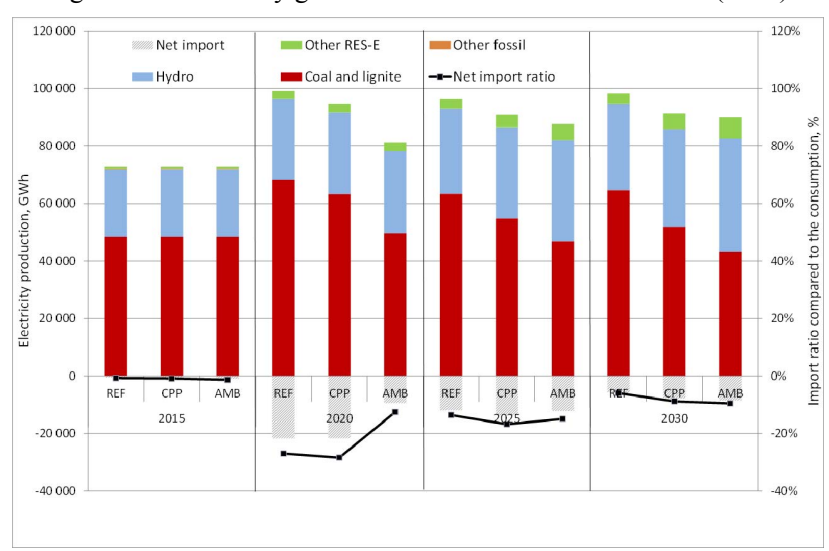

It is interesting to analyze the impact of carbon price on future generation mix keeping in mind that the assumed reference $\mathrm{CO}_{2}$ price in 2030 is $22 \mathrm{EUR} / \mathrm{t}$. By 2030, regional producers face the European carbon price in all scenarios. In the AMB scenario (assumes higher hydro capacity expansion than the other two scenarios) coal-based production decreases gradually (and sharply at a EUR $40 / \mathrm{t}$ carbon price) and is substituted by imports. This shift is mirrored in the decreasing carbon emissions. Gas-based production is not competitive in the region: it can only be profitable at even higher carbon price levels $(50 \mathrm{EUR} / \mathrm{t})$.

Figure 2 Regional electricity mix with different $\mathrm{CO}_{2}$ prices in the AMB scenario (2030)

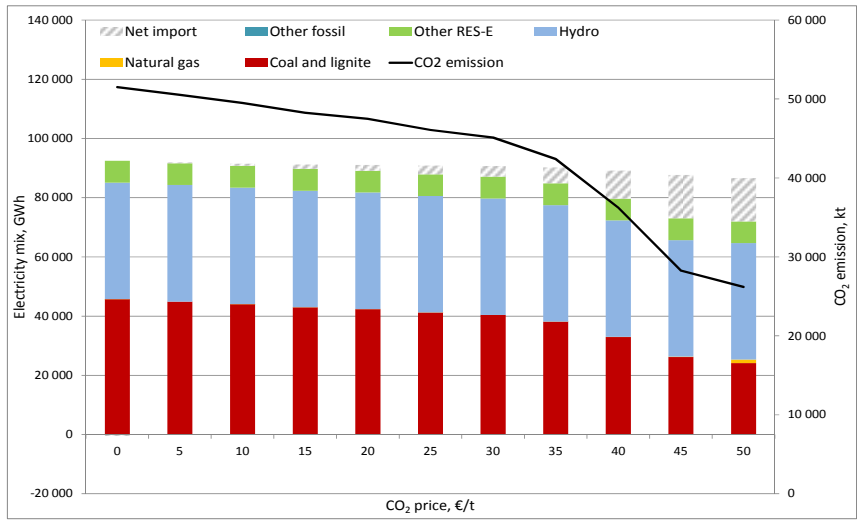

Hydropower plays an important role in the region, with high shares of hydro capacity present in almost all of the assessed countries. Albania has the greatest share, relying almost exclusively on hydropower, but the share of hydro generation capacity is also high in Bosnia and Herzegovina and Montenegro. This raising security of supply concerns as in dry years electricity imports can increase rapidly. This is a reason why most SEE countries are cautious about further increasing their share of hydro capacities, as to do so would increase their exposure to meteorological conditions (i.e. to the quantity and seasonality of precipitation).

In order to investigate the extent of this concern in the future, sensitivity assessment was carried out that assumes lower precipitation levels than in the REF, CPP and AMB scenarios. In the REF, CPP and AMB scenarios, hydro 
utilisation rates are modelled as the average over the past eight years, while in the sensitivity runs we use the lowest utilisation rate in the past eight years. As droughts usually occur in the same years throughout the region, we modelled the sensitivity runs accordingly: all analysed countries experience a lower level of precipitation. This is an important assumption, since drought affects these countries in a similar way and drives import and export prices upwards in a similar pattern.

In addition to the $\mathrm{CO}_{2}$ sensitivity assessment discussed above, we focus on two additional aspects: the substitution possibilities within the country to compensate for the loss in hydro generation; and the impacts on the export-import positions.

Figure 3 Electricity mix change in the case of low hydro availability in the region (2015-2030)

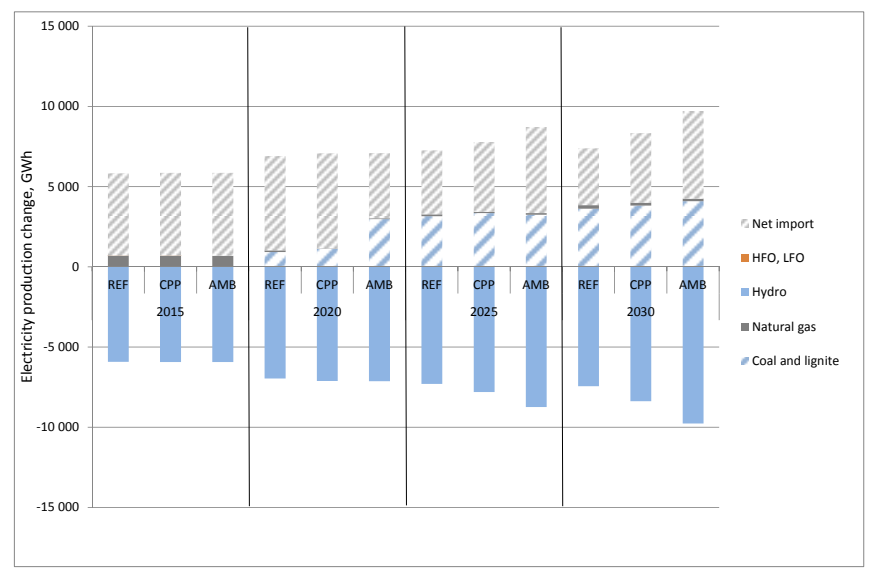

The loss of hydro generation in years when there are unfavourable hydrological conditions is mainly substituted by import in the first period then increasingly by coal- and lignite-based generation in all scenarios as new coal capacities gradually increase (in Serbia and Bosnia and Herzegovina). The limited amount of gas-based generation in 2015 in Macedonia is crowded out by these new lignite plants. Albania and Montenegro is the most vulnerable to the loss of hydro generation and would need to rely on import almost exclusively even in 2030. On the other hand, Serbia will be able to export even in dry years being less dependent in hydro generation and due to its ambitious fossil capacity plans. The price impact of droughts in the region is EUR 7-8/MWh in the short and EUR 3-4/MWh in the long run. The difference is mainly due to the capacity expansion between 2015 and 2020 in the region. Transmission capacity increase could further reduce the long term impact of drought.
Figure 4 Generation mix and net import change in the case of low hydro availability in the analyzed countries (2030)

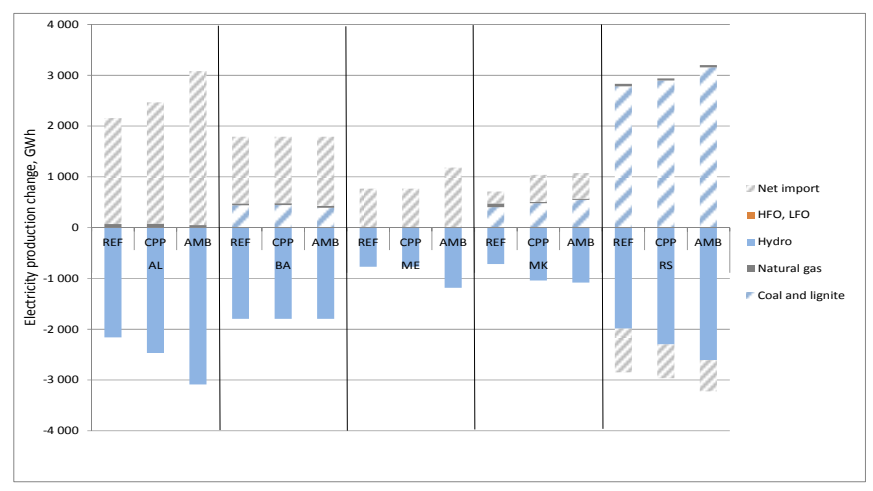

\section{CONCLUSIONS}

Vulnerability due to weather dependent hydro generation is a policy issue that needs to be tackled if the available hydro potential is to be exploited more in the future in the SEE region. We have seen before that a dry year can cause significant generation loss: in Albania approx. 15\%, in Montenegro $11 \%$ (2030, as a sensitivity analysis of the REF scenario).

If SEE countries remain outside any carbon pricing regime (either EU ETS or a comparable national scheme) than the current policy direction of self-sufficient generation based on fossil units will result in - if coupled with crossborder capacity expansion - increasing fossil export to the rest of Europe and hence carbon leakage. The lock-in to this fossil development path is hardly compatible with the EU membership aspirations of these countries. The joining of region's countries to the EU with such a generation capacity structure will pose a serious political challenge: threatening the 2030 and 2050 GHG emissions targets of an enlarged Union or - in case of instant and full application of the ETS the underutilization of relatively new fossil generation assets. This would mean considerable stranded investment costs for the electricity sectors of these countries that already rely on significant external financing for its renewable and crossborder capacity expansion projects.

Higher interconnection level would help to ease this problem, as demand could be covered even in dry years from import. Higher interconnection level helps to reduce the number of new coal plants as countries will have unconstrained access to the capacities. In addition in high precipitation years extra production could be traded to EU without constraints.

Several countries plan new gas units but these plans are contingent on the development of gas transmission infrastructure that is currently not there. In addition, the competitiveness of these gas plants is highly dependent on $\mathrm{CO}_{2}$ prices. Coal based generation is crowded out by import at a $40 \mathrm{EUR} / \mathrm{t} \mathrm{CO}_{2}$ level.

Our sensitivity assessment confirms that the region is sensitive to meteorological conditions: in the short term, 
severe droughts could drive up prices by EUR 7-8/MWh, and in the long term by EUR 3-4/MWh.

\section{REFERENCES}

[1] C. Stambolis, "Preliminary Findings of IENE's "SE Europe Energy Outlook 2015/2016"', The European Commission JRC \& The Energy Community Secretariat Joint Workshop on Energy Scenarios for South Eastern Europe, Vienna, 15 December 2015

[2] R. Demiglio, "Integration of the Balkan region into the JRC-EUTIMES model", The European Commission JRC \& The Energy Community Secretariat Joint Workshop on Energy Scenarios for South Eastern Europe, Vienna, 15 December 2015

[3] M. Tot, "Exploring energy scenarios for South-East European Countries in a regional context - A case study for Albania", The European Commission JRC \& The Energy Community Secretariat Joint Workshop on Energy Scenarios for South Eastern Europe, Vienna, 15 December 2015

[4] L. Szabó, "Support for Low Emission Development in South Eastern Europe: Decarbonisation modelling in the electricity sector", The European Commission JRC \& The Energy Community Secretariat Joint Workshop on Energy Scenarios for South Eastern Europe, Vienna, 15 December 2015

[5] United States Agency for International Development (USAID), "Assessment of Energy Developments in Albania for the period 20122030", January 2015

[6] "Montenegrin Energy Strategy up to 2030", Godine (Bijela Knjiga), 2014
[7] Research Center for Energy and Sustainable Development, Macedonian Academy of Sciences and Arts (RCESD-MASA), "First Biennial Update Report on Climate Change", September 2014

[8] The Energy Strategy of Serbia, 2015 (draft)

[9] EC Impact Assessment on the policy framework for climate and energy from 2020 up to 2030, SWD 2014(15) final

[10] Council Directive 2003/96/EC of 27 October 2003 restructuring the Community framework for the taxation of energy products and electricity

[11] Directive 2001/80/EC of the European Parliament and of the Council of 23 October 2001 on the limitation of emissions of certain pollutants into the air from large combustion plants

[12] Directive 2010/75/EU of the European Parliament and of the Council of 24 November 2010 on industrial emissions (integrated pollution prevention and control)

[13] A. Mezősi, Zs. Pató and L. Szabó, "Decarbonisation modelling in the electricity sector, Country report: Albania", unpublished, 2015

[14] A. Mezősi, Zs. Pató and L. Szabó, "Decarbonisation modelling in the electricity sector, Country report: Macedonia", unpublished, 2015

[15] A. Mezősi, Zs. Pató and L. Szabó, "Decarbonisation modelling in the electricity sector, Country report: Montenegro", unpublished, 2015

[16] A. Mezösi, Zs. Pató and L. Szabó, "Decarbonisation modelling in the electricity sector, Country report: Serbia", unpublished, 2015

[17] A. Mezősi, Zs. Pató and L. Szabó, "Decarbonisation modelling in the electricity sector, Regional report", unpublished, 2015

[18] A. Mezösi, L. Szabó, "Model based evaluation of electricity network investments with regional importance," in Proc. $11^{\text {th }}$ International Conference on the European Energy Market, 2014. p1-6 